\title{
KOMPETENSI RASIO DALAM EPISTEMOLOGI HUKUM ISLAM (Studi terhadap Pemikiran Ibn Hazm 994-1064 M)
}

\section{Khairuddin}

\begin{abstract}
When Andalucia was as center of Umayyad Dynasty in Europe, school of Malik ibn Anas became the formal school of state, and at the time, Ibn Hazm opposed such state school legalization and called to refer to the Qur'an and Sunnah. The commitment of Ibn Hazm to return religious problem, especially Islamic law, to text of the Qur'an and Sunnah and also because of his relation with Abu Daud al-Asfahani made his school be known as school of literalism. The rational dimension in Islamic law epistemology of Ibn Hazm can be met in deconstructive and reconstructive aspect of his criticism discourse toward epistemology of all existing schools at that time. Thus, it can be known that Ibn Hazm literalism is based on critical dimension and not on textual literalism. The most striking rational aspect in the Islamic law epistemology of Ibn Hazm can be seen in the concept of argument (aldalil).
\end{abstract}

Key Words; Epistemology, Islamic Law and Reconstruction

$$
\begin{aligned}
& \text { الملخص: عندما كان الأندلس مركزا لدولة بنى أمية في اروبا, فصار مذهب مالك بن أنس } \\
& \text { مذهبا للدولة. و حينئذ عارض ابن حزم ذلك القرار لمذهب الدولة ودعا الى الرجوع إلى } \\
& \text { القرآن والسنة. ولعزمه هذا وعلاقته مع أبى داود الأصفهانى فاشتهر مذهبه بالمذهب } \\
& \text { الظاهري. و ان البعد العقلى فن نظريات حكم ابن حزم يوجد في ناحية تفكيك البنية والبنية } \\
& \text { من جديد فن النطاق النقدى عن الإبيستمية لكل مذهب من المذاهب الموجودة فن ذلك } \\
& \text { الوقت. ومن هذا، يعرف ان ظاهرية ابن حزم مبنية على البعد النقدى و ليس على الظاهر } \\
& \text { النصى مطلقا. اما البعد العقلى البارز فن نظرية حكم الإسلام لإبن حزم فيمكن ان ينظر فن } \\
& \text { مفهوم الدليل. }
\end{aligned}
$$

\section{Pendahuluan}

Hukum bertujuan untuk mengendalikan masyarakat. Hukum adalah sebuah sistim yang ditegakkan untuk melindungi hak-hak individu maupun 
hak-hak kolektif. Sistim hukum di setiap masyarakat memiliki sifat, karakter dan ruang lingkupnya sendiri. Sama halnya, Islam memiliki sistim hukum tersendiri yang dikenal dengan fiqh. ${ }^{1}$ Hukum dipahami sebagai peraturan atau seperangkat norma yang mengatur tingkah laku manusia dalam masyarakat, baik berupa kenyataan yang tumbuh dan berkembang dalam masyarakat maupun yang dibuat dengan cara tertentu dan ditegakkan oleh penguasa. Bentuknya mungkin hukum yang tidak tertulis seperti hukum adat atau hukum tertulis dalam peraturan perundang-undangan seperti hukum Barat. ${ }^{2}$ Hukum Barat adalah hukum yang dibuat untuk mengatur kepentingan manusia dalam masyarakat tertentu menyangkut hubungan manusia dengan manusia dan benda dalam masyarakat.

Hukum Islam dipahami lebih luas, mengatur hubungan sesama manusia, manusia dengan pencipta dan benda dalam masyarakat pada seluruh sisi kehidupan; etika, keagamaan, politik dan ekonomi. Hukum Islam bersumber dari wahyu dan akal manusia. ${ }^{3}$ Wahyu menentukan normanorma dan konsep dasar dan dalam banyak hal mendobrak sistim hukum kesukuan Arab pra-Islam.

Allah mengutus Muhammad saw dan membawa agama yang benar dan mudah (al-hanafiyyah al-samhah). Hal ini digambarkan dalam sabdanya bahwa agama yang disukai Allah SWT adalah al-hanafiyyah al-samhah. ${ }^{4}$ Kebenaran dan kemudahan itu dilengkapi dengan tata hidup praktis yang serba meliputi (al-syari'ah al-jami'ah). ${ }^{5}$ Meskipun demikian dalam sifatnya yang menyeluruh terdapat dua hal yang berbeda; hal-hal yang parametris ${ }^{6}$, ajaran dan norma agama yang tidak berubah dan hal-hal yang dinamis, ajaran dan norma agama yang bisa berubah sesuai dengan perubahan waktu, tempat dan kondisi.

Norma dan ajaran yang irrasional, tidak berubah disebabkan pergeseran waktu dan perbedaan tempat adalah simpul-simpul kepercayaan (al-'aqâid) dan peribadatan (al-'ibâdat), untuk persoalan ini diberikan penjelasan secara rinci (mufashshal) dan sempurna serta dijelaskan dengan nash-nash yang serba meliputi. Karena itu, tidak seorangpun dibenarkan menambah atau mengurangi.

Selanjutnya persoalan yang berubah disebabkan pergeseran waktu dan perbedaan tempat, seperti kemaslahatan sipil (al-mashalih al-madaniy) serta berbagai persoalan politik dan perang, untuk hal ini diberikan penjelasan secara garis besar (mujmal) supaya sesuai dengan kemaslahatan manusia di setiap zaman dan dengan ketentuan tersebut para pemegang wewenang dan pengambil keputusan (wali al-amr) mencari petunjuk dalam upaya menegakkan kebenaran dan keadilan. ${ }^{7}$ 
Pada masa rasulullah saw masih hidup, para sahabat belum mendapatkan kesulitan untuk menjelaskan ketentuan hukum terhadap tindakan seseorang, karena setiap kejadian yang mereka saksikan dan alami dapat mereka ruju' langsung kepada rasulullah saw. Selain itu menurut Ahmad Hasan, ketika rasulullah saw. masih hidup para sahabat tidak tidak semuanya merespon persoalan-persoalan yang yang terjadi secara filosofis dan njilimet. Mereka yakin perbuatan rasulullah-lah satu-satunya yang menjadi standar ukuran dan nilai perbuatan mereka. Belajar wudhu' melalui yang mereka lihat dari praktek rasulullah saw., demikian juga shalat, serta praktek ibadah dan mu'amalah lainnya. ${ }^{8}$

Setelah rasulullah saw wafat, sesuai dengan tuntutan zaman, waktu dan kondisi, sahabat mengalami persoalan agama (terutama dalam masalah hukum) yang tidak pernah mereka lihat, ketahui dan bahkan tidak pernah mendengar persoalan tersebut waktu bersama rasulullah saw. Sedangkan pada sisi lain persoalan tersebut harus diselesaikan berdasarkan keputusan hukum syari'at, dari sisi lain yang akan menyelesaikan persoalan itu merupakan tanggung jawab mereka sendiri. Dalam menanggapi persoalan semacam ini, mereka terbagi dalam dua kelompok; pertama, mereka yang meyakini bahwa agama Islam yang mereka anut merupakan agama sempurna dengan pedoman al-Qur'an dan sunnah rasulullah saw. Kelompok kedua, memandang bahwa yang dimuat dalam al-Qur'an merupakan pedoman yang bersifat universal dan masih membutuhkan pengembangan dan interpretasi.

Dalam menghadapi kasus hukum baru, kelompok pertama berusaha merujuk pada al-Qur'an, apabila tidak ditemukan, mereka mengingat praktek yang pernah dilakukan nabi sebelumnya seperti yang mereka alami tersebut. Apabila ditemukan pada salah satu sumber (al-Qur'an dan praktek nabi), mereka menyelesaikannya dengan kedua sumber itu, meskipun dengan memaksakan makna literalnya, apabila tidak ada justru sebahagian mereka lebih memilih diam daripada harus menggunakan pendapatnya sendiri.

Berbeda dengan kelompok sahabat pertama, kelompok sahabat yang kedua, mereka merujuk nash, baik al-Qur'an maupun praktek yang dilakukan nabi dalam hal yang serupa, apabila dijumpai kasus yang serupa mereka melakukan interpretasi terhadap nash dan berusaha menemukan unsur-unsur maslahah dari peristiwa yang terjadi. Artinya mereka tidak saja banyak menggunakan rasio dalam memahami hukum dan menyikapi peristiwa dan persoalan yang muncul, tetapi lebih dari itu, memprediksikan suatu peristiwa yang belum terjadi dan menentukan hukumnya. ${ }^{9}$ 
Apabila dilihat perkembangan pemikiran Islam, kedua kelompok yang telah disebut di atas merupakan cikal bakal munculnya ilmu fiqh yang sering diidentikkan dengan istilah hukum Islam. Menurut Nurcholish Madjid bahwa dalam sejarah pemikiran islam, fiqh yang paling kuat mendominasi paham keagamaan orang-orang muslim akan agama mereka. Sehingga karenanya paling banyak membentuk bagian terpenting cara berpikir mereka. Kenyataan ini dapat dikembalikan kepada berbagai proses sejarah pertumbuhan masyarakat muslim masa lalu dan kepada sebagian dari inti semangat ajaran agama Islam sendiri. ${ }^{10}$

Dalam sejarah perkembangan pemikiran Islam tercatat sederetan nama mujtahid yang keseluruhannya berupaya menggali hukum Islam dari sumbernya yang asasai, al-Qur'ân dan sunnah. Kenyataannya sampai saat ini hanya beberapa orang saja nama-nama mujtahid tersebut yang masih dikenal dan sering disebut orang.

Ibn Hazm adalah salah seorang mujtahid potensial yang diduga sebagai penerus mazhab zhahiriy. Ibn Hazm merupakan tokoh yang fenomenal. Pada dirinya melekat gelar al-zhahiriy karena berpegang secara harfiah pada teksteks nash. ${ }^{11}$ Tetapi meskipun demikian, Ibn Hazm merupakan salah seorang pemikir muslim yang menekuni multi disiplin ilmu keislaman. Ia dikenal ahli dalam ilmu kalam (teologi), hadis, ushul fiqh, politik, bahasa, sejarah dan fiqh, bahkan juga psikologi. Kepiawaiannya di bidang ilmu pengetahuan pada waktu itu tidak diragukan, hal ini dapat dibuktikan ketika ilmuwan sezamannya banyak bertaqlid, ${ }^{12}$ ternyata ia menentang keras sikap taqlid. Menurutnya seseorang tidak dibenarkan taqlid kepada orang lain, baik ulama tersebut masih hidup, maupun telah meninggal. Dengan menentang sikap taqlid, maka ijtihad menjadi wajib sesuai dengan batas kemampuan masing-masing, karena makna ijtihad itu sendiri merupakan batas kesanggupan untuk mencari hukum agama yang telah diwajibkan bagi hambanya. ${ }^{13}$

Dalam kajian hukum Islam, Ibn Hazm dikenal sebagai tokoh literal, artinya selalu berpendapat sesuai dengan apa adanya pada teks nash. Dengan ungkapan ini seakan pada diri Ibn Hazm tidak ada fungsi rasio dalam menemukan hukum Islam, karena sudah cukup dengan nash (alQur'an dan Sunnah) secara tekstual. Pada sisi lain, Ibn Hazm sangat menganjurkan ijtihad, bahkan sampai pada tingkat wajib dan konsekwensinya taqlid diharamkan.

Mengamati fenomena di atas, menarik untuk diteliti lebih lanjut melalui buku ushul figh-nya yang monumental al-Ihkâm fi Ushûl al-Ahkâm, bagaimanakah kompetensi rasio dalam epistemologi hukum Islam Ibn 
Hazm?, bagaimana ia menyelesaikan peristiwa hukum yang muncul kemudian yang secara tekstual tidak ditemukan dalam nash ?.

Tulisan ini membongkar wacana epistemologi hukum Islam Ibn Hazm dengan merujuk pada karya monumentalnya. Selain itu, untuk mengungkapkan metode berpikir (istimbath) dalam berijtihad yang menurutnya merupakan kewajiban.

\section{Al-Qur'ân Sebagai Sumber Hukum Islam}

Sebelum membicarakan kedudukan al-Qur'ân sebagai sumber utama hukum Islam, lebih dahulu dijelaskan pengertian epistemologi dan kaitannya dengan hukum Islam, sehingga mempermudah memahami pembahasan berikut. Epistemologi, berasal dari bahasa Yunani, terdiri dari kata "episteme" dan "logos". Episteme artinya pengetahuan atau ilmu pengetahuan (knowledge), sedangkan logos berarti informasi atau teori. Dengan demikian, pengertian epistemologi secara etimologi adalah teori pengetahuan. ${ }^{14}$ Pada mulanya epistemologi merupakan cabang filsafat yang membicarakan tentang pengetahuan manusia. Berbicara tentang epistemologi paling tidak harus membicarakan hakikat pengetahuan, sumber pengetahuan, bagaimana cara (metode) mendapatkan pengetahuan dan jangkauan serta ruang lingkup pengetahuan. ${ }^{15}$

Dalam kaitannya dengan kajian ini, fiqh disebut sebagai ilmu yang dirumuskan dari hasil penalaran dalil nash (al-Qur'ân dan Sunnah) dengan menggunakan metodologi yang telah disusun dengan apik serta sistematis yang disebut dengan ushûl fiqh. ${ }^{16}$ Dengan demikian epistemologi hukum Islam dipahami sebagai formulasi yang digunakan untuk mendapatkan hukum Islam. Jika term epistemologi dikaitkan dengan epistemologi hukum Islam Ibn Hazm, yang dimaksud dalam tulisan ini adalah formulasi Ibn Hazm tentang al-Qur'ân dan Sunnah sebagai sumber hukum serta metodologi yang digunakannya untuk mendapatkan ilmu fiqh dari nash.

Ibn Hazm meletakkan al-Qur'an sebagai sumber utama hukum Islam. Tidak terdapat perbedaan di kalangan umat Islam tentang kedudukan alQur'ân sebagai sumber utama hukum Islam. Perbedaan akan muncul ketika berbicara tentang apakah al-Qur'ân diposisikan layaknya buku undangundang yang harus diaplikasikan secara literal, atau harus mencari makna substansial, majaz atau yang esoterik dari kandungan teks tersebut. Berikutnya, apakah keumuman teks al-Qur'ân tetap diamalkan berdasarkan keumumannya, tanpa harus mencari pentakhsisnya yang lebih spesipik dan terarah. Kedua kemungkinan pemahaman tersebut akan mempengaruhi out put yang dihasilkan, juga memberikan corak tersendiri dalam kajian fiqh. 
Ibn Hazm mengklasifikasikan wahyu pada dua bagian, yaitu; (1) wahyu yang dibaca (al-Qur'ân) dan (2) wahyu yang diriwayatkan (khabar yang berasal dari nabi Muhammad saw). Lebih jelas, al-Qur'ân didefenisikan sebagai:

$$
\text { وحي متلو مؤلف تأليفا معجز النظام • } 17
$$

Wahyu yang dibaca tersusun dengan teratur dan susunannya mengandung mukjizat.

Penjelasan ini memberikan batasan yang tegas antara al-Qur'an dan sunnah rasulullah saw. Kata matluwwin dan muallafin dipahami bahwa alQur'an sebagai pedoman hidup manusia yang diturunkan Allah SWT. tanpa ada campur tangan Muhammad di dalamnya, karena itu al-Qur'an diterima rasulullah saw dengan cara dibacakan kepadanya, demikian juga dengan susunannya secara tauqify.

Wahbah al-Zuhaili, seorang ulama ushul fiqh kontemporer mendefinisikan al-Qur'ân sebagai;

$$
\begin{aligned}
& \text { هو كلام الله تعالى المنزل على رسول الله صلى الله عليه وسلم باللسان العريي للإِ عجاز بأقصر سورة منه, } \\
& \text { المكتوب في المصاحف المنقول بالتوار , المتعبد بتلاوته, المبدوء بسورة الفاتحة المختوم بسورة الناس. } 18 \text { بلاسل }
\end{aligned}
$$

Yaitu, Perkataan Allah SWT yang diturunkan kepada rasulullah saw dalam bahasa Arab mengandung mu'jizat termasuk juga surat yang terpendek, ditulis pada mushhaf, dinukil dengan cara mutawatir, merupakan ibadah membacanya, dimulai dengan surat al-Fâtihah dan ditutup dengan surat al-Nâs.

Kedua definisi di atas meggambarkan al-Qur'ân sebagai referensi utama ajaran Islam, termasuk hukum. Hukum yang ditetapkan al-Qurân wajib diikuti dan diamalkan sesuai dengan kandungannya.

Ibn Hazm tidak membedakan satu ayat al-Qurân dengan ayat al-Qur'an lainnya, dengan demikian kewajiban mengamalkan al-Qur'ân tanpa membedakan dilalahnya. Hal inilah yang mempengaruhi pemikiran fiqhnya, sehingga ia mengungkapkan "ber'amal dengan al-Qur' ân sesuai dengan makna literal ayat dan keumuman kandungannya".

Pengamalan ayat secara literal karena tujuan al-Qur'ân diturunkan antara lain sebagai petunjuk bagi manusia dan pembeda antara kebaikan dengan keburukan. ${ }^{19}$ Penerapan nash secara tekstual dipahami berdasarkan argumentasi rasional ('aqliyah) dan naqliyah (nash). Argumentasi pertama, kemampuan rasional menyakini bahasa sebagai media penyampaian keterangan (bayan), selain itu bahasa merupakan susunan kata yang mempunyai arti. Apabila perkataan (kalam) yang terdapat dalam alQur'an dan hadis tidak menjelaskan makna yang sebenarnya, lalu pesan apa 
yang dapat dipahami dari nash, bahkan bagaimana manusia saling berinteraksi. ${ }^{20}$

Argumentasi kedua, Ibn Hazm mengutip beberapa ayat al-Qur'an yang mencela orang yang berpaling dari makna literal dan merubahnya dengan makna lain (al-Baqarah; 75 dan al-Nisa'; 46)

Menurut Ibn Hazm, makna yuharrifunahu adalah orang yang memalingkan makna harfiah dalam bahasa kepada makna lain. ${ }^{21}$ Menurut Qurthubi makna yuharrifunahu adalah perlakuan orang Yahudi yang menukar makna ayat dalam Taurat dari yang haram menjadi halal dan sebaliknya karena mengikuti nafsu mereka. ${ }^{22}$ Ibn Katsir menafsirkannya sebagai sikap orang Yahudi yang menakwilkan maknanya dengan tidak tepat. ${ }^{23}$ Penafsiran yang sama juga disampaikan M. Quraish Shihab. ${ }^{24}$

Menurut al-Qasimi ada tiga kemungkinan pemahaman kata tahrif yaitu; menukar kata atau kalimat dengan kata atau kalimat lain, melakukan tasybih yang bathil atau takwil yang fasid sehingga terjadi perobahan makna, menyembunyikan kebenaran yang mereka terima dari Rasul saw, kemudian menyampaikan berita yang tidak benar kepada orang lain. ${ }^{25}$

Lebih lanjut menurut Ibn Hazm, orang yang meninggalkan makna literal teks al-Qur'an padahal dapat dipahami secara bayani, lalu ia mencari makna lain tanpa ada tunjukan dari lafaz ayat al-Qur'an yang lain maupun sunnah rasulullah saw, atau ijma' ulama mu'tabarah yang menegaskan perobahan makna dari literal kepada makna lain, atau perobahan itu merupakan keharusan berdasarkan keniscayaan inderawi yang telah pasti menurut akal, berarti orang tersebut membuat kebohongan kepada Allah SWT. ${ }^{26}$ Tetapi sebaliknya bila ditemukan indikasi yang telah disebutkan, makna itulah yang harus dijadikan sebagai pegangan, lebih jelas Ibn Hazm mengungkapkan:

$$
\begin{aligned}
& \text { " ونحن لا ننكر الإنتقال من حكم أوجبه القرآن اوالسنة إذ جاء نص أخر ينقلنا عنه, }
\end{aligned}
$$

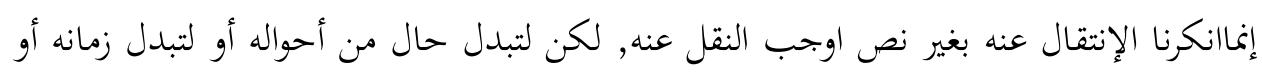

$$
\begin{aligned}
& 27 \text { مكانه, فهذا هو الباطل الذى انكرناه. }
\end{aligned}
$$

"kami tidak mengingkari perobahan hukum dari apa yang telah ditetapkan nash (al-Qur'an dan sunnah) apabila ada nash lain yang mengindikasikan perubahannya, tetapi kami membantah perubahan hukum tanpa ada dalil sebagaimana biasanya di sebutkan karena berubahnya kondisi, waktu atau tempatnya".

Dari ungkapan ini diketahui bahwa Ibn Hazm memberikan peluang untuk menginterpretasi teks nash, tetapi tokoh ini sangat hati-hati dan menjadikan interpretasi sebagai sesuatu yang dharurah atau sebagai emergency 
exit, artinya jika pemahaman literal tidak menghantarkan pada makna dan tujuan esensial al-Qur'an, boleh melakukan interpretasi. Ibn Hazm menjelaskan lagi bahwa akal tidak pernah bertentangan dengan al-Qur'ân sebagaimana halnya al-Qur'ân tidak bertentangan dengan akal. Adapun dasar logika yang digunakan Ibn Hazm adalah "segala sesuatu yang difirmankan Allah SWT adalah benar dan tidak satupun yang bertentangan dengan akal, bahkan sebelum diturunkan kepada kita secara keseluruhan, mungkin untuk kita ketahui. Setelah Allah SWT menurunkan kepada kita, maka menjadi wajib, benar dan pasti “.28

Menurut Ibn Hazm segala yang benar menurut burhan, ditemukan secara literal dalam al-Qurân dan sabda nabi saw. Setiap orang yang berusaha meneliti dan memahami, ia akan mampu melihatnya. ${ }^{29}$ Istilah inilah yang disederhanakan Hegelian dengan ungkapan "semua yang qur'ani adalah masuk akal dan setiap yang masuk akal adalah qur'ani ". 30

Pemahaman di atas berdasarkan teks nash al-Qur'ân, surat al-Nisâ', ayat 59:

Hai orang-orang yang beriman, ta ‘atilah Allah dan ta`atilah Rasul (Nya), dan ulil amri di antara kamu. Kemudian jika kamu berlainan pendapat tentang sesuatu, maka kembalikanlah ia kepada Allah (Al Qur'an) dan Rasul (sunnahnya), jika kamu benar-benar beriman kepada Allah dan hari kemudian. Yang demikian itu lebih utama (bagimu) dan lebih baik akibatnya.(al-Nisa'; 59)

Menurut Ibn Hazm ketaatan kepada Allah SWT adalah ketaatan kepada kandungan al-Qur'ân. Selanjutnya, ia menjelaskan Islam adalah akidah dan syari'ah yang disampaikan dengan bahasa Arab, begitu juga al-Qur'ân diturunkan dalam bahasa Arab. Dengan demikian persoalan agama dapat ditemukan dalam al-Qurân secara bayani tanpa harus melakukan takwil batini (penafsiran metaforis-alegoris-esoterik) atau takwil rasional, karena bahasanya dapat dipahami dengan mudah.

Penerapan logika berpikir di atas, dalam wilayah fiqh disebutkan alQur'ân sebagai kitabun mubin dan mubin berarti jelas bagi mereka yang memahami bahasa al-Qurân. Sedangkan kejelasan (bayan) al-Qur'an itu ada tiga: pertma, bagian yang jelas dengan sendirinya sehingga tidak membutuhkan tambahan penjelasan, kedua, bagian yang membutuhkan penjelasan dan penjelasannya ada dalam al-Qur'ân sendiri, ketiga, bagian yang membutuhkan penjelasan dan penjelasannya ada dalam sunnah. ${ }^{31}$

Isu penting kedua posisi keumuman nash. Menurut Ibn Hazm teks umum terbagi dua; mufassar dan mujmal. Teks mufassar yang mungkin dipahami dan diterapkan secara umum sesuai dengan pemahaman tekstualnya. ${ }^{32}$ Untuk teks mujmal yang sulit dipahami secara literal, harus 
dicari penjelasannya berdasarkan teks nash yang lain atau melalui ijma'. ${ }^{33}$ Ketika menafsirkan ayat tentang perampokan, Al-Jassas mengemukakan bahwa hukuman bagi perampok muslim dan non muslim tetap disamakan berdasarkan keumuman ayat kecuali ada dalil lain yang menyebutkan untuk melihat sebab turunnya ayat. ${ }^{34}$

\section{Otoritas Sunnah Sebagai Sumber Hukum Islam}

Secara bebas istilah sunnah dan hadis memiliki kesamaan arti, yaitu tradisi yang terdiri dari ucapan, perbuatan dan termasuk juga di dalamnya ketetapan Nabi saw. Tetapi kajian kritis atas kedua istilah ini mengalami perkembangan. Pada awalnya makna kedua istilah tersebut tidak identik. Menurut harfiah sunnah berarti jalan setapak, praktik, tindak tanduk, kebiasaan atau perilaku. ${ }^{35}$ Istilah ini mengalami perkembangan dan pergeseran makna serta mengandung arti praktek normatif atau model prilaku seseorang, kelompok maupun masyarakat tertentu. Termasuk di dalamnya ketentuan-ketentuan Tuhan yang telah menjadi hukum Alam. Berdasarkan pengertian inilah tindakan Allah SWT terhadap generasigenerasi yang lalu, dalam al-Qur'ân disebut sebagai sunnatullah. ${ }^{36}$ Dengan demikian, mengikuti sunnah generasi masa lalu berarti merujuk pada praktek dan adat kebiasaan yang pernah mereka lakukan.

Istilah sunnah yang digunakan untuk pengertian praktek masyarakat atau prilaku seseorang, memiliki unsur normatif. Sifat normatif inilah yang membuatnya berbeda dengan istilah lain yang sinonim dengannya. Ketika istilah sunnah ini digunakan dalam doktrin dan kajian hukum Islam, dipahami sebagai praktek normatif yang dicontohkan oleh Rasulullah saw dan selama beliau masih hidup mendapat perhatian serius dari sahabat. ${ }^{37}$

Pada generasi berikutnya, pengertian sunnah semakin berkembang menjadi praktek umum kaum muslimin yang mula-mula. Pernyataan ini sebagaimana dapat dilihat pada ungkapan Malik al-sunnah 'indanâ " sunnah menurut kami“38 Dalam kajian ini tidak difokuskan pada pembahasan pengertian sunnah dan hadis, karena pada masa-masa terakhir tidak lagi tercermin perbedaan antara keduanya. Ahmad Hasan menyebutkan penyamaan kedua istilah ini dimulai sejak pasca Syafi'i. ${ }^{39}$ Logika berpikir Ahmad Hasan ini karena Syafi'i menentang dengan gigih arti sunnah yang telah berlaku di masyarakat muslim dan mendesak untuk mengartikan sunnah sebagai tradisi yang dijamin asli berasal dari rasulullah saw. Ia lebih mengutamakan hadis dari rasulullah saw yang dijamin keasliannya daripada praktek mapan yang telah disepakati oleh kaum muslimin. Dengan demikian, sunnah diidentikkan dengan hadis. ${ }^{40}$ 
Ketika membicarakan sunnah sebagai sumber hukum dalam Islam, Ibn Hazm mendasarkan pemikirannya pada al-Qur'an surat al-Nisa' ayat 59 yang menjelaskan keharusan patuh kepada Allah SWT dan Rasulu-Nya ${ }^{41}$ Selain itu, juga terdapat pada surat al-Hasr ayat 7.42 Kedua ayat tersebut dipahami Ibn Hazm dengan jelas bahwa mentaati rasul adalah ketaatan terhadap syari'at yang dibawa oleh rasul.

Ibn Hazm tidak membedakan kewajiban ta'at pada al-Qur'ân dan sunnah rasulullah saw. Menurutnya, sesuatu yang diucapkan, dilakukan dan ditetapkan rasulullah saw merupakan wahyu yang diriwayatkan. Pandangannya ini didasarkan pada al-Qurân surat al-Kahfi ayat 110 dan surat al-Najm ayat 3-5.

Ayat ini 110 surat al-Kahfi menjelaskan perbedaan yang prinsipil antara manusia biasa dengan Rasul Allah. Secara biologis tidak ada perbedaan, tetapi Rasul mendapat bimbingan langsung dari Allah SWT, karena itu ucapan, perbuatan dan ketetapan rasul merupakan wahyu. Mengomentari ayat ini, Imam ibn Jarir berkata bahwa Nabi tidak punya ilmu pengetahuan kecuali apa yang diwahyukan Allah. ${ }^{43}$ Dengan demikian, yang membedakan rasul dari manusia biasa adalah rasul menerima wahyu. ${ }^{44}$

Ibn Hazm menjelaskan, pada kedua ayat ini diketahui bahwa ucapan rasul merupakan wahyu. Ungkapan yang sama juga dikemukakan oleh alJassas. ${ }^{45}$ Sebagaimana layaknya wahyu, ketaatan terhadap al-Qur'ân sama wajibnya dengan ketaatan terhadap sunnah (hadis), demikian sebaliknya larangan mengingkari al-Qur'ân sama halnya larangan mengingkari hadis, karena keduanya dalam pemeliharaan Allah SWT, inilah yang dimaksud dengan "jika kamu berbeda/berbantah tentang sesuatu hal, kembalilah kepada Allah (al-Qur'ân) dan rasul (hadis)". Jelas, al-Qur'ân mengungkapkan keharusan mengembalikan persoalan terhadap ketentuan al-Qur'an dan sunnah rasulullah SAW. ${ }^{46}$

Pembelaan Ibn Hazm terhadap sunnah rasulullah saw tidak berarti ia mengamalkan setiap hadis yang dijumpainya tanpa meneliti kualitas hadis tersebut, bahkan sebaliknya Ibn Hazm sangat kritis menerima dan menilai sebuah hadis. Sikap kritis Ibn Hazm terhadap hadis dapat dilihat dari pemikirannya tentang klasifikasi hadis. Menurutnya, berdasarkan kuantitas perawi, hadis dapat dikelompokkan pada hadis mutawatir dan ahad. ${ }^{47}$ Hadis mutawatir adalah;

$$
\text { هو مانقلته كافة بعد كافة حتى تبلغ به النبى صلى الله عليه وسلم. } 48
$$

Hadis mutawatir adalah hadis yang diriwayatkan oleh sejumlah orang dari yang lainnya dan bersambung rangkaian sanadnya hingga rasulullah saw. 
Defenisi hadis mutawatir yang ditawarkan Ibn Hazm tidak terdapat perbedaan yang signifikan dengan defenisi ulama hadis lainnya. Perbedaannya hanya pada pencantuman sifat perawinya.

Lebih lanjut Ibn Hazm menjelaskan bahwa pada hadis mutawatir penekanannya tidak hanya pada jumlah perawi yang meriwayatkannya, tetapi juga pada tingkat ke-adilan dan ke-dhabitan para perawinya. ${ }^{4}$

Adapun Hadis ahad adalah hadis yang diriwayatkan seorang perawi dari perawi lain dan bersambung sampai pada rasulullah saw.

Tidak terdapat perbedaan di kalangan ulama ushul fiqh menjadikan hadis mutawatir sebagai dalil hukum. Berbeda dengan hadis mutawatir, hadis ahad terdapat perbedaan ulama ketika menjadikannya sebagai dalil hukum. Ibn Hazm melihat, apabila hadis ahad tersebut diriwayatkan oleh orang yang 'adil, 50 dhabit dan riwayatnya bersambung hingga rasulullah saw, hadis tersebut wajib diamalkan. ${ }^{51}$ Logika yang digunakan Ibn Hazm adalah fakta sejarah, yaitu ketika rasulullah saw mengutus sahabat menyiarkan ajaran agama ke daerah-daerah, seperti $\mathrm{Mu}^{\prime} \mathrm{adz}$ ibn Jabal, tidak ada reaksi untuk tidak menerima berita tersebut, padahal mereka hanya terdiri dari seseorang saja. Peristiwa seperti ini merupakan praktek langsung yang diperlihatkan rasulullah dan dialami umat Islam masa awal bahwa tingkat nilai kebenaran suatu berita (hadis) tidak hanya diukur dari instrumen-instrumen yang ada, tetapi dilihat dari tingkat akurasi berita dan penyampai berita itu sendiri.

Dengan demikian, diketahui ternyata al-Qurân dalam pandangan Ibn Hazm sebagai sumber utama hukum Islam, sedangkan sunnah berfungsi sebagai pembayan al-Qur'an.

\section{Kriteria Ijma' yang Dijadikan Sumber Hukum Islam}

Penetapan Ijma' sebagai salah satu sumber hukum dalam Islam merupakan polemik di kalangan mujtahid sejak periode awal sampai sekarang. Untuk itu perlu dijelaskan hakikat ijma' menurut terminologi yang dipahami mujtahid, karena berbeda konsep tentang ijma', berbeda pula sikap memposisikannya dalam hirarki sumber hukum Islam dan berbeda pula dalam memandang hasil ijma' itu sendiri.

Al-Sarakhsi misalnya mendefenisikan ijma' sebagai "kesepakatan mujtahid umat Islam setelah rasul wafat pada suatu masa tentang suatu persoalan agama". ${ }^{52}$ Sedangkan Hudlari Bek, mendefinisikan ijma' sebagai "kesepakatan seluruh mujtahid umat Islam pada suatu masa tentang hukum syar'i" ${ }^{53}$ Dua definisi ijma' ini tidak terdapat pebedaan yang signifikan, pada definisi Hudlori Bek objek ijma' lebih mengarah pada kasus hukum dan pada 
definisi Syarakhsi objek ijma' adalah persoalan yang lebih umum, tentunya termasuk juga kasus hukum.

Kedua definisi di atas menjelaskan bahwa ijma' merupakan hasil ijtihad, baik ijtihad fardi (personal) atau jamâi (kolektif) yang telah mendapat legislasi dari mujtahid lain. Dalam hal ini, Ahmad Hasan menjelaskan, ijma' merupakan suatu prinsif untuk menjamin kebenaran produk hukum yang baru muncul sebagai hasil ijtihad, baik dengan metode qiyas atau metode yang lain. ${ }^{54}$

Berdasarkan penjelasan di atas ijma' dapat dipahami sebagai produk dan methode ijtihad. Dipahami sebagai produk ijtihad dan bahkan sebagai tindakan lanjutan menguatkan hasil ijtihad. Dengan demikian tidak ada keharusan mengikuti ijma', tetapi kedudukannya sebanding dengan produk ijtihad lain yang tidak punya sifat hukum mengikat.

Apabila dilihat Pemikiran Ibn Hazm, ijma' lebih dipahami sebagai produk ijtihad karena merupakan hasil kebijakan yang diambil oleh ulu alamr. Menurut Ibn Hazm, ijma' memiliki sifat hukum mengikat karena ijma' itu adalah nash. Dasar pemikiran Ibn Hazm adalah makna ayat al-Qur'an surat al-Nisa' ayat 59.55 Menurutnya keharusan mengikuti ijma' merupakan pemahaman terhadap kalimat " " pada ayat tersebut. Ulu al-amr dipahami sebagai pemerintah (pengambil kebijakan) yang juga sebagai ulama, keta'atan terhadap ulu al-amr dalam teks nash disejajarkan dengan keta'atan kepada Allah SWT dan rasul-Nya. ${ }^{56}$ Dengan demikian lanjut Ibn Hazm, tidak ada perbedaan kewajiban taat kepada Allah SWT dan rasulnyaNya dengan keta'atan kepada ulu al-amr.

Ibn Hazm menjelaskan, kewajiban mematuhi ulu al-amr tersebut adalah ulu al-amr yang dalam keputusannya tidak bergeser dari nash. Logika seperti ini yang mendasari pemikirannya bahwa ijma' itu sesungguhnya adalah nash, karena itu wajib ditaati. Argumen ini diperkuat ibn Hazm dengan mengutip ayat 51 surat al-Nur.

Qurthubi menjelaskan makna ayat ini sebagai bentuk kepatuhan orang muhajirin dan anshar pada awal Islam terhadap berita dan ajaran agama yang disampaikan rasulullah saw. ${ }^{57}$ Lebih lanjut Thabari menjelaskan ayat ini menerangkan sikap keengganan orang munafiq mengikuti hukum yang dibawa rasulullah saw dan kepasrahan orang mukmin dengan hukum dan ajaran tersebut. ${ }^{58}$ Dengan demikian penolakan ijma' merupakan sikap yang tidak seutuhnya patuh terhadap aturan ajaran agama.

Mengomentari pendapat sebahagian ulama yang menjadikan ayat "jika kamu berselisih paham tentang sesuatu, maka kembalikanlah kepada Allah SWT. dan rasulullah saw" sebagai dasar adanya qiyas dalam istimbath hukum, Ibn Hazm 
menjelaskan, ayat ini bukan untuk melegalkan qiyas, tetapi merupakan larangan Allah SWT terhadap sikap taqlid dan mengikuti pendapat mujtahid serta sebagai perintah untuk mengikuti al-Qurân dan sunnah, bukan yang lain. ${ }^{59}$

Dengan Argumentasi di atas, Ibn Hazm menolak kriteria ijma' yang ditawarkan mazhab lain. Dalam mazhab malik misalnya, yang merupakan pengikut Imam Malik ibn Anas (w.798 M/179 H) “sesungguhnya ijma' yang dijadikan hujjah adalah kesepakatan (ijma') penduduk Madinah". ${ }^{60}$

Dari paparan di atas terlihat bahwa konsep ijma' yang ditawarkan Ibn Hazm berbeda dengan mujtahid lain, menurutnya ijma' merupakan ketetapan dan kesepakatan pemimpin yang juga sebagai ulama tentang suatu perkara berdasarkan nash. Dengan demikian, maka menta'ati ijma' sama kewajibannya dengan menta'ati al-Qurân dan sunnah. ${ }^{61}$

\section{Istishhab al-Hal}

Menurut ulama ushul Istishhab ${ }^{62}$ merupakan metode istimbath hukum dengan memberlakukan ketetapan hukum atau menafikannya berdasarkan ketetapan hukum awal sebelum ada dalil yang merobahnya. Istishhab sering juga disebut sebagai baraah al-ashliyah yang dapat dibagi menjadi baraah alashliyah al-syr'iyah dan baraah al-ashliyah al-'aqliyah. ${ }^{63}$

Menurut Abu Zahrah, istishhab merupakan pengistimbathan hukum yang berdasarkan akal, bukan melalui nash, ${ }^{64}$ bahkan lebih dari itu, menurut Wael B. Hallaq istishhab bukan metode pemikiran hukum Islam (istimbath), tetapi hanya perinsip hukum yang dianggap tetap valid sebelum ada dalil lain yang mengubah asumsi tersebut. 65

Menurut Ibn Hazm istishhab merupakan metode penerapan hukum berdasarkan nash. Karena itu ia tidak mengakui keberadaan istishhab bentuk kedua "baraah al-ashliyah al-'aqliyah". Ibn Hazm menyebutkan "apabila ada persoalan hukum yang telah ditetapkan nash tetap berlaku selama tidak ada dalil lain yang membatalkannya. Apabila ada yang menyatakannya berubah, sementara tidak ada dalil al-Qurân maupun hadis yang telah tetap, maka penyataannya ditolak". ${ }^{66}$

Dengan begitu perobahan waktu, tempat dan kondisi tidak berpengaruh pada perubahan hukum. Perubahan hukum hanya bisa terjadi dengan adanya dalil nash yang mengindikasikan perobahan. ${ }^{67}$ Lain halnya dengan perobahan nama yang dapat merubah ketentuan hukum. Khamar misalnya apabila telah berubah menjadi cuka tidak haram, kotoran tijna apabila telah menjadi tanah maka tidak lagi sebagai najis. ${ }^{6}$ 
Menurut Ibn Hazm istishhab terdiri dari empat bentuk; (1) tidak boleh menghalalkan persoalan yang telah diharamkan Allah SWT dan rasul-Nya, (2) tidak boleh mengharamkan persoalan yang telah dihalalkan Allah SWT dan rasul-Nya, (3) mewajibkan hukum yang telah diwajibkan Allah SWT dan rasul-Nya, (4) tidak boleh mewajibkan sesuatu pada dirinya padahal Allah SWt. dan rasul-Nya tidak mewajibkan, seperti mewajibkan haji ke tempat selain Ka'bah yang berada di Makkah, mewajibkan shalat sampai enam waktu dalam sehari semalam. ${ }^{69}$

Berdasarkan penjelasan di atas, diketahui bahwa dalam kerangka Ibn Hazm istishhab merupakan pemberlakuan nash terhadap hukum yang telah ditetapkan secara umum sebelumnya.

\section{Urgensi Ijtihad}

Ijtihad (Ar: ijtihâd) ${ }^{70}$ merupakan mashdar dari ijtahada-yajtahidu, terambil dari kata al-juhd, bermakna al-thaqah dan al-quwwah (daya, kemampuan dan kekuatan) atau berakar dari kata al-jahd yang berarti al-masyaqqah (kesulitan, kesukaran). Berdasarkan makna tersebut ijtihad secara bahasa dipahami sebagai "badzl al-wus'i wa al-majhud" (pengerahan daya dan kemampuan) ${ }^{71}$, atau "pengerahan daya dan kemampuan dalam aktivitas yang berat dan sukar". ${ }^{72}$ Ibn Hazm menambahkan "pengerahan daya, kemampuan dan kekuatan untuk memperoleh sesuatu yang sangat dibutuhkan dan diharapkan serta diyakini keberadaannya. ${ }^{73}$

Berdasarkan pengertian kebahasaan, ada dua unsur pokok dalam ijtihad; (1) daya atau kemampuan, dan (2) obyek yang sulit, berat dan sangat dibutuhkan. Daya atau kemampuan meliputi daya fisik-material, mentalspritual dan intelektual. Ijtihad sebagai terminologi keilmuan dalam Islam tidak terlepas dari dua unsur tersebut. Akan tetapi, karena kegiatan keilmuan lebih banyak bertumpu pada kegiatan intelektual, pengertian ijtihad lebih banyak mengacu pada pengerahan kemampuan intelektual dalam memecahkan berbagai bentuk kesulitan yang dihadapi, individu maupun umat secara menyeluruh.

Dalam melihat obyek ijtihad, ada dua aliran yang berkembang dalam sejarah pemikiran hukum Islam yaitu; pertama, aliran mukhati'ah yang cenderung berpendapat bahwa Allah SWT telah menetapkan ketentuan hukum secara dalam al-Qur'ân dan hadis. Kedua, aliran mushawwibah yang berpendapat bahwa Allah SWT tidak menetapkan ketentuan hukum yang rinci berupa halal, haram, boleh dan tidak boleh atas sesuatu masalah, tetapi ketentuan hukum yang bersifat umum dan global. Penerapan hukum ini sangat tergantung kepada ijtihad para mujtahid. ${ }^{74}$ 
Perbedaan pandangan seperti inilah yang membuat mereka berbeda dalam merumuskan pengertian ijtihad secara syari'at. Ghazali sebagai ulama Syafi'iyah mendefinisikan ijtihad sebagai "pengerahan kemampuan secara maksimal untuk mendapatkan hukum-hukum syar'i. ${ }^{75}$ Rumusan lain yang lebih spesifik dikemukakan al-Amidi "mencurahkan kemampuan dalam mendapatkan hukum-hukum syara' yang bersifat zhanni, sehingga dirinya tidak mampu lagi mengupayakan yang lebih dari ketentuan itu" ${ }^{76}$

Berdasarkan rumusan ijtihad di atas diketahui bahwa ijtihad dalam bidang hukum Islam ialah pengerahan kemampuan intelektual secara optimal untuk mendapatkan hukum pada tingkat zhanni. Berbeda dengan Ibn Hazm yang merumuskan ijtihad sebagai "pencurahan kemampuan dalam mendapatkan hukum suatu kasus di mana hukum itu dapat diperoleh". ${ }^{77}$ Lebih lanjut Ibn Hazm menjelaskan bahwa ijtihad dalam syari'at merupakan;

$$
\text { اجتهاد في الشريعة هو استنفاد الطا قة في طلب حكم النازلة حيث يوجد ذالك الحكم. }
$$

"Ijtihad adalah upaya pengerahan kemampuan secara optimal untuk mendapatkan hukum yang diturunkan Allah SWT dan diyakini telah ada dalam syari'at itu sendiri “. Ibn Hazm meyakini bahwa segenap hukum syari'at telah dijelaskan Allah kepada kita. ${ }^{78}$ Tugas mujtahid adalah memunculkan hukum dari kedua sumber tersebut. Upaya memunculkan hukum dari kedua sumbernya, itulah yang disebut ijtihad menurut pendapat ini. Ibn Hazm menyebutkan bahwa al-Qur'an dan sunnah sudah lengkap dan sempurna, dengan demikian tidak mungkin ada masalah yang tidak ada jawabannya dalam nash karena telah sempurna diturunkan (Q.S. al-Maidah; 3).

Ibn Arabi memahami kalimat " كمال الدين" sebagai sempurnanya seluruh kewajiban, pensucian masjidil haram, yakni orang musyrik tidak dibenarkan melaksanakan haji dan thawaf. Selain itu juga mengandung makna kemenangan bagi orang Islam di haramain serta doa diterima pada hari 'Arafah.79

Menurut Wahbah Zuhaili, kesempurnaan agama adalah kesempurnaan seluruh aturan tentang halal dan haram dalam agama. ${ }^{80}$ Berdasarkan pemahaman di atas, diketahui makna kesempurnaan agama yang dimaksud dalam ayat adalah kesempurnaan aturan Allah SWT tentang kewajiban dan larangan serta perkara halal dan haram dalam agama.

Ayat 38 surat al-An'am dipahami beragam oleh mufassirin, tetapi mereka sependapat bahwa makna kitab itu ada dua, yaitu kitab yang terdapat di Lauh al-Mahfuzh dan al-Qur'an. Wahbah Zuhaili memahami maknanya dengan kitab yang terdapat di Lauh al-Mahfuzh ${ }^{81}$ sedangkan al- 
Razi memahaminya sebagai al-Qur'an. Razi menguatkan argumentasinya dengan argumen bayaniyah dan burhaniyah, berdasarkan kaidah kebahasaan setiap alif dan lam yang masuk pada isim mufrad maknanya umum diketahui, sedangkan yang umum diketahui umat Islam adalah al-Qur'an. Argumentasi kedua bahwa keseluruhan rangkaian ayat al-Qur'an adalah untuk mengetahui Allah SWT, menjelaskan maksud agama dan menjelaskan hukum-hukum Allah SWT kepada manusia, dengan demikian tidak ada manfaatnya bagi manusia mengetahui sesuatu yang rinci di Lauh al-Mahfuzh, sedangkan yang diterima dan dipahami adalah al-Qur'an. ${ }^{82}$

Fungsi al-Qur'an sebagai tibyan, hudan, rahmah dan busra (al-Nahal; 89) dipahami mufassir bahwa al-Qur'an sebagai sumber yang menjelaskan seluruh ilmu yang bermanfaat untuk kepentingan urusan dunia dan agama yang dapat menghantar manusia pada tingkat kesempurnaan dan dapat meraih kebahagiaan yang abadi. ${ }^{83}$

Menurut Ibn Hazm, tidak ada alasan bagi kita mencari hukum di luar kandungan al-Qur'an dan hadis. Atas dasar ini Ibn Hazm menolak segala metode ijtihad yang ditawarkan ushuliyyin seperti qiyas, istihsan, istishlah dan sebagainya, karena dinilai sebagai hukum yang didasarkan atas akal sematamata. Ia menggunakan metode ijtihad tersendiri yang disebutnya dengan aldalil ${ }^{84}$ (dilalah al-nash dan dilalah al-ijma'), ia menerima ijma' dengan syarat ijma' tersebut dilandaskan kepada al-Qur'an dan hadis.

Membahas pentingnya ijtihad dalam konsep Ibn Hazm erat kaitannya dengan persoalan taqlid. Artinya apabila ijtihad hidup tidak akan terjadi taqlid dan sebaliknya taqlid akan menghentikan produktivitas ijtihad. Menurut Ibn Hazm keseluruhan ajaran syari'at telah tercakup dalam nash dan dapat dipahami berdasarkan teks-teks nash tersebut karena keterangan dan dilalahnya secara zahir jelas, Dengan demikiat lanjut Ibn Hazm tidak dibenarkan taqlid dalam ajaran agama. Ia menjelaskan:

“Tidak boleh mengikuti pendapat orang lain yang masih hidup maupun yang telah meninggal. Setiap orang mesti melakukan ijtihad sesuai kesanggupannya. Barangsiapa yang bertanya tentang ajaran agamanya berarti ia ingin tahu bagaimana yang telah ditetapkan Allah SWT dalam syari'at. Apabila ia termasuk orang yang paling tidak mengerti agama, maka wajib bertanya kepada orang yang ahli dalam bidang agama. Apabila diberikan fatwa hendaklah bertanya "apakah fatwa tersebut sesuai dengan ketentuan Allah?". Jika sesuai, pendapat tersebut dipegang lalu diamalkan, jika dijawab "ini pendapatku, atau ini qiyas, atau ini pendapat seorang sahabat, tabiin, ulama fiqh klasik atau kontemporer, atau ia diam, atau diucapkan saya tidak tahu", maka tidak boleh mengambil pendapatnya, 
tetapi harus bertanya kepada orang lain (yang juga ahli dalam masalah agama). Orang yang menyerukan seluruhnya wajib mengikuti pendapat mufti, berarti ia menyerukan yang bathil, berarti juga mangikuti pendapat yang tidak ditemukan dasarnya baik dari al-Qur'an dan Sunnah. Hal ini merupakan pendapat yang bathil karena tidak ada dalil". 85

Dalam pernyataannya yang lain, Ibn Hazm bahkan secara tegas mencela sikap bertaqlid kepada para sahabat, tabiin dan para imam mazhab;

"Setiap orang yang taqlid kepada sahabat, tabiin, Malik, Abu Hanifah, Syafi'i, al-Auzai', Ahmad dan Daud al-Ashfahani harus menyadari bahwa mereka itu semua bebas darinya di dunia dan akhirat atau hari kesaksian kelak. Ya Allah Engkau Maha Tahu bahwa kami tidak menjadikan seseorang sebagai sumber hukum kecuali Firman-Mu dan sabda nabi-Mu, tentang segala sesuatu yang kami perselisihkan dan pertentangkan mengenai hukumnya. Kami sama sekali tidak merasa berat mengikuti apa yang diputuskan oleh nabi-Mu, walaupun karenanya seluruh penduduk bumi berbeda dan membenci kami. 86

Dengan demikian dapat dipastikan sikap Ibn Hazm menentang taklid dan mewajibkan ijtihad. Ia menjelaskan bahwa setiap orang harus mengerti tentang yamg halal dan yang haram untuk dirinya, harus mengerti rukun haji untuk orang yang punya kelapangan harta untuk menunaikannya, demikian juga orang yang punya harta harus mengerti tentang cara pengelolaan zakatnya. Menurut Ibn Hazm seorang muslim wajib berijtihad sesuai dengan batas kemampuannya meskipun hanya dengan mempertanyakan dasar hukum urusan agama yang diketahuinya. ${ }^{87}$

Sikap Ibn Hazm menentang taqlid dan mewajibkan ijtihad ini tidak terlepas dari pengaruh situasi dan perkembangan pemikiran masyarakat Islam di zamannya, terutama di bidang hukum Islam atau fiqh di dunia Islam pada umumnya khususnya Andalus. Pada abad kelima Hijriyah, era yang dilalui Ibn Hazm, perkembangan pemikiran Islam sudah diarahkan pada kegiatan men-syarah literatur fiqh yang ada, sehingga mereka tidak lagi memiliki semangat berijtihad langsung pada al-Qur'an dan hadis, tetapi cukup memfadakan literatur fiqh yang ada, khusus Andalus dengan mazhab Malik-nya. ${ }^{88}$

Demikianlah pandangan Ibn Hazm tentang urgensi ijtihad yang sangat ditekankan dalam beragama, menurutnya sampai pada tingkat wajib sesuai dengan kafasitas kemampuan masing-masing. Anjuran yang kuat untuk berijtihad menjadikan sikap taqlid sebagai sikap tercela. 


\section{Antara Konsep al-Dalil dan Qiyas}

Ibn Hazm mendasarkan pemikiran hukumnya kepada al-Qur'an, sunnah, ijma', istishab al-hal dan al-dalil. ${ }^{9}$ Al-Dalil didasarkan pada al-Qur'an, hadis dan ijma' tetapi tidak dalam bentuk qiyas. Al-Dalil dalam bentuk lain yang tidak berpegang kepada illah fighiyah tetapi didasarkan kepada istilahistilah logika.

Ibn Hazm membagi al-dalil menjadi tujuh macam; pertama, premis pertama dan kedua adalah teks kemudian diambil kesimpulan yang tidak tersurat dalam teks, seperti hadis nabi "setiap yang memabukkan adalah khamar, setiap khamar hukumnya haram, konklusi yang dihasilkan adalah setiap yang memabukkan adalah haram" ; kedua, memasukkan kata kerja bersyarat dalam suatu kalimat bersyarat; ketiga, makna yang ditunjukkan oleh kata itu dengan sendirinya berarti menafikan makna lain yang tidak sesuai; keempat, apabila status hukum suatu persoalan tidak tersurat halal atau haram, hukumnya menjadi mubah; kelima, 'aks al-qadhaya ", yaitu membalik predikat menjadi objek dan objek menjadi predikat; keenam, apabila suatu kata menjadi objek sebuah makna dan dalam makna ini ada keniscayaan-keniscayaan yang dipahami dari kata itu; ketujuh, al-qadlaya almutadarrijah (transitifisme logis). ${ }^{90}$

Dari ungkapan di atas, jelas, Ibn Hazm tidak bermaksud mendasarkan "bayan" kepada qiyas, menganalogikan bagian kepada bagian lain seperti yang dilakukan Syafii, tetapi didasarkan pada asas-asas logika dengan berpegang kepada kaidah-kaidah logika, kaidah-kaidah akal universal seperti peralihan dari dua premis kepada kesimpulan yang merupakan keniscayaan, atau peralihan dari lazim kepada malzum, dari general kepada partikuler dan kaidah-kaidah logika lain yang diterapkan oleh Ibn Hazm.

Ibn Hazm menghindari "ta'lil" (kausasi) yang digunakan dalam qiyas figh. Dengan demikian, jika meninggalkan ta'lil niscaya qiyas tidak lagi memiliki objek. Penolakannya terhadap ta'lil ternyata tidak hanya dalam fiqh, ia juga menolak ta'lil dalam gramatika, berdasarkan ungkapan tersebut ia menolak qiyas dalam segala disiplin ilmu.

Dari penjelasan konsep al-dalil yang ditawarkan Ibn Hazm, diketahui sesungguhnya berbeda dengan qiyas yang digunakan oleh imam mazhab lain. Dalam qiyas, persoalan-persoalan utama yang didiskusikan berhubungan dengan unsur pokok argumen analogis, persyaratanpersyaratan yang harus dipenuhi secara individual dan prinsip-prinsip yang mengatur hubungan di antaranya. Unsur pokoknya ada empat; (1) kasus baru (far') yang membutuhkan sebuah solusi hukum; (2) kasus asli (ashl) yang ada ketetapannya dalam sumber-sumber utama al-Qur'an, sunnah dan atau 
ijma'; alasan rasio legis (illat), sifat umum yang ada pada kasus baru dan kasus asli; dan (4) norma hukum (hukm) yang dinisbatkan kepada kasus baru dan karena terdapat kesamaan antara dua kasus yang ditransfer dari kasus lama ke kasus baru. Penjelasan ini dapat dipahami dengan jelas dari pengertian qiyas secara bahasa, menurut ilmu logika dan juga dalam terminologi ulama ushul. Ulama ushul menjelaskan qiyas adalah:

Mengungkapkan hukum syara' yang tidak terdapat dalam nash dengan menganalogikannya pada hukum yang ada dalam nash karena kesamaan illat pada keduanya menurut mujtahid. ${ }^{91}$

Berdasarkan di atas, dipahami sesungguhnya mengistimbathkan hukum berdasarkan qiyas merupakan upaya untuk mengungkapkan hukum yang tidak ada dalam nash. Menurut Ibn Hazm ini merupakan kekeliruan karena agama Islam adalah agama yang sempurna (Q.S. al-Maidah: 3) dan tidak ada sesuatupun yang luput dari pengamatan Allah SWT yang tidak dimuat dalam nash (Q.S. al-An'am: 38) juga rasulullah saw berfungsi sebagai pembayan kitab Allah SWT.

Tidak diragukan bahwa ijtihad merupakan kebutuhan yang diperlukan sepanjang masa. Eksistensi syari'at Islam tidak terlepas dari peranan ijtihad. Dari itu, tidak keliru pendapat Ibn Hazm yang menjelaskan bahwa pintu ijtihad itu tidak pernah tertutup sepanjang masa. Atas dasar inilah ia berpendapat bahwa berijtihad hukumnya wajib bagi setiap individu muslim yang telah mukallaf berdasarkan kemampuan yang mereka miliki. Kensekwensinya, taklid merupakan perbuatan yang dilarang secara mutlak.

Ijtihad yang diwajibkan Ibn Hazm bukan ijtihad yang lepas tanpa dasar, tetapi ia punya frame tersendiri dalam menyikapi ijtihad, yakni ijtihad berdasarkan syari'at. Artinya menurut Ibn Hazm Allah tidak pernah memerintahkan seseorang untuk kembali (taqlid atau ittiba') kepada pendapat seseorang dalam masalah agama, tetapi diperintahkan kembali kepada Allah dan rasul-Nya, yakni al-Qur'an dan sunnah rasulullah saw.

\section{Kesimpulan}

Berdasarkan epistemologi hukum Islam ibn Hazm dapat di konklusikan bahwa dalam hukum Islam tidak dapat dipisahkan antara nash dan rasio. Indikasi pernyataan ini dapat dilihat dari apa yang diajarkan al-Qur'an dan al-hadits.

Berpikir dalam al-Qur'an diungkapkan dalam berbagai kata, sebagaimana diketahui kata ya'qilu (memakai akal) yang terdapat pada 48 ayat dalam berbagai bentuk katanya. Kata ini dalam bahasas Indonesia menjadi akal. Kata lain adalah nazhara (melihat secara abstrak) yang terdapat 
dalam 30 ayat. Dalam bahasa Indonesia kata ini menjadi nalar, penalaran dan sebagainya. Kata lainnya adalah tafakkara (berpikir) yang terkandung dalam 19 ayat. Kata "berpikir" dalam bahasa Indonesia jelas berasal dari kata ini. Perbuatan berpikir juga diungkapkan dengan kata Fahima dan dalam bahasa Indonesia ia menjadi "paham". Kata Faqiha dalam berbagai bentuknya terdapat dalam 16 ayat juga menggambarkan perbuatan berpikir. Dalam alQuran juga dijumpai kata Tadzakkara (memperhatikan, mempelajari) dalam 40 ayat. Dalam bahasa Indonesia kata ini dikenal sebagai mudzakarah, bertukar pikiran, kata lainnya lagi adalah tadabbara yang juga mengandung arti berpikir. Selain dari kata-kata di atas terdapat pula dalam al-Qur'an kata 'ulu al-albab (orang berfikir), 'ulu al-ilm (orang berilmu), 'ulu al-abshar (orang berpandangan) dan 'ulu al-nuha (orang bijaksana). Semua itu adalah sebutan yang memberi sifat berpikir yang terdapat pada manusia.

Hadis sebagai sumber kedua ajaran Islam ternyata memberi dukungan

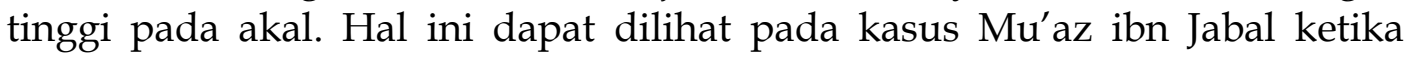
diutus nabi Muhammad saw mengajarkan Islam ke Yaman.

Dalam epistemologi hukum Islam penggunaan akal (rasio) selalu disebut dengan ijtihad, yakni pengerahan seluruh daya dan upaya untuk menemukan hukum dari al-Quran dan sunnah Rasulullah saw. Besarnya peran rasio dalam hukum Islam juga dapat dilihat pada hirarki sumber hukum Islam. Menurut syi'ah Ja'fariyah sumber hukum Islam adalah alQur'an, sunnah dan akal. Penggunaan rasio dalam mazhab Abu Hanifah sangat kental pada penggunaan istihsan. Pada mazhab Malik penggunaan rasio dapat dilihat pada mashalih al-mursalah dan pada mazhab Syafi' dapat dilihat pada penggunaan qiyas.

Kompetensi rasio dalam epistemologi hukum Islam Ibn Hazm dapat dilihat dari konsep al-dalil yang ia tawarkan. Yaitu merupakan konsep yang tidak dikenal pada mazhab lain, konsep al-dalil didasarkan dan lahir dari alQuran, hadits, dan ijma', bukan dalam bentuk qiyas tetapi dalam bentuk lain yang tidak berpegang pada illah fighiyyah, tetapi didasarkan kepada istilahistilah logika.

Ibn Hazm membagi al-dalil menjadi tujuh macam; pertama, premis pertama dan kedua adalah teks dan kemudian diambil kesimpulan yang tidak tersurat dalam teks; kedua, memasukkan kata kerja bersyarat dalam suatu kalimat bersyarat; ketiga, makna yang ditunjukkan oleh kata itu dengan sendirinya berarti menafikan makna lain yang tidak sesuai; keempat, status hukum suatu hal yang tidak tersurat, halal atau haram, maka hukumnya mubah; kelima, apa yang ia sebut dengan " 'aks al-qadhaya", yakni membalik predikat menjadi objek dan objek menjadi predikat; keenam, suatu kata 
Al-Fikra: Jurnal Ilmiah Keislaman, Vol. 3, No. 2, Juli-Desember 2004

menjadi objek sebuah makna dan dalam makna ini ada keniscayaankeniscayaan yang dipahami dari kata itu; ketujuh, al-qadlaya al-mutadarrijah (transitifisme logis).

${ }^{1}$ Fiqh secara ethimologi berarti "paham yang mendalam". Kata fiqh atau yang seakar dengannya dalam al-Qur'ân terdapat pada 20 ayat. Menurut hasil penelitian Muhammad Rasyid Ridha (1865 - 1935 M), 19 kata di antaranya berarti kedalaman paham, kedalaman ilmu yang menyebabkan diambil manfaat daripadanya. Lihat Muhammad Rasyid Ridha, Tafsir al-Qur'ân al-Halim, (Beirut: Dâr al-Ma'ârif, t.th.), jilid IX, h. 420-421

Sedangkan secara terminologis, fiqh sering didefinisikan dengan, seperangkat norma guna mengatur perbuatan lahir (praktis) manusia, baik pribadi maupun kolektif yang diperoleh dari penafsiran al-Qur'ân dan hadis rasulullah saw melalui penalaran yang sistematis. Lihat Al Yasa Abubakar, Ahli Waris Sepertalian Darah: Kajian Perbandingan Terhadap Penalaran Hazairin dan Penalaran Fikih Mazhab, (Jakarta: INIS, 1998), h. 1

${ }^{2}$ Lihat C.S.T. Kansil, Pengantar Ilmu Hukum dan Tata Hukum Indonesia, (Jakarta: Balai Pustaka, 1989), h. 39 Bandingkan juga dengan Mohammad Daud Ali, Asas-asas Hukum Islam, (Jakarta: Rajawali Pers, 1991), h. 45 - 46

3Dalam ushûl Syi'ah sumber fiqh adalah al-Qur'ân, sunnah, ijma' dan akal. Lihat Muhammad Abu Zahrah, Ushîl al-Figh al-Ja'farî, (Beirut: Dâr al-Fikr, 1956), h. 28

${ }^{4}$ Hadis tersebut diriwayatkan Imam Ahmad dalam Musnad-nya, Thabrani, Bazzar dan lainnya dari Ibn Abbas, katanya: "Ada yang bertanya kepada rasulullah saw. wahai rasulullah, manakah di antara agama-agama ini yang disukai Allah SWT? "beliau menjawab: "yang benar dan mudah". Bazzar menyampaikan dengan redaksi yang berbeda "yang manakah agama Islam itu" sebagai ganti "manakah di antara agama-agama". Thabrani meriwayatkan hadis dari Abu Hurairah dengan redaksi lain: "Sesungguhnya agama yang disukai Allah adalah agama yang benar dan Mudah".

${ }^{5}$ Sayyid Sabiq, Fiqh al-Sunnah, (Mesir: Dâr al-Fath, 1998), jilid I, h. 11

${ }^{6}$ Istilah yang sering digunakan menjelaskan persoalan-persoalan yang tidak boleh diijtihadiahkan ini adalah "ta'abbudi", arti harfiahnya adalah sesuatu yang bersifat ibadah, sehingga seakan tidak ada peluang bagi rasio untuk memikirkannya, seperti persoalan metafisika karena tidak mampu dijangkau akal, juga persoalan akidah karena diyakini sebagai fitrah manusia yang sesuai sepanjang zaman, dengan demikian hanya dibutuhkan untuk mewujudkan keyakinan (akidah) yang kuat. Selanjutnya lihat penjelasan Mahmud Syaltut, Al-Islâm'Aqîdah wa Syarî'ah, (Kairo: Dâr al-Qolam, 1966), h. 56

${ }^{7}$ Ibid.

${ }^{8}$ Ahmad Hasan, The Early Develovment of Islamic Jurisprudence, alih bahasa oleh Agah Garnadi, (Bandung: Pustaka, 1984), h. 23

${ }^{9}$ Ibid.

${ }^{10}$ Nurcholish Madjid, Islam Doktrin dan Peradaban, (Jakarta: Paramadina, 2000), h. 235

${ }^{11 J a l a l u d d i n ~ R a h m a t, ~ T i n j a u a n ~ K r i t i s ~ A t a s ~ S e j a r a h ~ F i g h: ~ D a r i ~ F i q h ~ a l-K h u l a f a ' ~ a l-R a s y i d i n ~}$ Hingga Mazhab Liberalisme dalam Budhy Munawar Rachman (ed), Kontekstualisasi Doktrin Islam dalam Sejarah, (Jakarta: Paramadina, 1994), h. 272

${ }^{12}$ Banyaknya mereka yang taqlid pada waktu itu karena memandang ijtihad yang dilakukan Imam Mazhab sudah menjawab tantangan zaman. Rasa puas dengan pendapatpendapat imam mazhab yang ada, tanpa merasa pelu merujuk langsung pada al-Qur'an ataupun sunnah rasulullah saw. justru menimbulkan sikap fanatisme dan kejumudan dalam 
dunia Islam. Lihat Muhammad Hudhari Bek, Tarikh al-Tasyri' al-Islami, (Mesir: al-Maktabah al-Tijariyah al-Kubra, 1970), h. 237

${ }^{13} \mathrm{Abu}$ Muhammad Ali Ibn Ahmad ibn Sa'id ibn Hazm al-Andalusi al-Zhahiry, selanjutnya ditulis Ibn Hazm, Al-Muhalla, jilid I, (Beirut: Daar al-Jail, 1997), hh. 66-67.

${ }^{14}$ Lihat: Lorens Bagus, Kamus Filsafat, ( Jakarta: Gramedia, 2002 ) cet. Ke-3, h. 212 dan lihat juga Rizal Mustansir dan Misnal Munir, Filsafat Ilmu, (Yogyakarta: Pustaka Pelajar, 2001), h. 16 dan bandingkan juga dengan Juhaya S. Praja, Filsafat dan Metodologi Ilmu dalam Islam dan Penerapannya di Indonesia, (Jakarta: Teraju, 2002), h. 121.

15Jujun S. Suria Sumantri, Filsafat Ilmu: Sebuah Pengantar Populer, (Jakarta: Pustaka Sinar Harapan, 1993), h. 119

${ }^{16}$ Dalam kajian ushûl fiqh, nash disebut dalil, ulama ushûl fiqh abad pertengahan atau yang masih mengadopsi pola berpikir ulama abad pertengahan, akan diperoleh penjelasan bahwa dalil atau sumber fiqh tersebut ada yang berasal dari wahyu dan ada pula yang berasal dari bukan wahyu, yang berasal dari wahyu yang disepakati sebagai wahyu adalah al-Qur'ân dan Sunnah, meskipun ada sebahagian ulama yang tidak sepakat mengatakan sunnah sebagai wahyu, malahan menyampaikan kritikan terhadap kemurnian sunnah. Sedangkan yang berasal dari bukan wahyu adalah produk akal seperti penggunaan ijma', qiyas, istihsan, maslahah mursalah, istishab, 'urf, mazhab shahabi, syar'u man qoblana dan sadd al-zari'ah. Lihat misalnya Wahbah al-Zuhaili, Ushûl al-Fiqh al-Islâmî, (Beirut: Daar alFikr, 1986), h. 417

Pandangan tentang dalil atau sumber hukum Islam ini berkembang seiring dengan perkembangan zaman, pemikiran sosial budaya dan problematika yang dihadapi. Pemerhati ushûl fiqh kontemporer berusaha memperluas cakupan nash itu, sehingga sumber ushûl fiqh bukan lagi hanya nash al-Qur'ân dan sunnah, tetapi nash-nash kauniyah (alam semesta), nash-nash ijtimaiyah (sosial masyarakat) dan nash-nash wujdaniyah (hati nurani dan spritualitas diri manusia menjadi dalil yang perlu, bahkan mesti diperhatikan, meskipun prioritas utama tetap pada nash al-Qur'ân dan Sunnah. Lebih jauh dari itu, menurut Hassan Hanafi, sudah saatnya perioritas baru harus ditujukan pada realitas daripada teks, demikian pula ijtihad individu dan konsensus umat diperioritaskan atas teks-teks tertulis dalam rangka mendorong ijtihâd dan merangsang dilakukan teorisasi langsung terhadap realitas tanpa mediasi teks. Lihat Hassan Hanafi, Oposisi Pasca Tradisi, alih bahasa oleh Khairon Nahdiyyin, (Yogyakarta: Syarikat Indonesia, 2003), h. 49-50.

${ }^{17}$ Abu Muhammad Ali ibn Ahmad ibn Sa'id ibn Hazm, selanjutnya ditulis Ibn Hazm, Al-Ihkâm fi Ushôl al-Ahkâm, selanjutnya ditulis Al-Ihkam...,(Beirut: Dâr al-kutub al-ilmiah, t.th.), jilid 1, h. 95

${ }^{18}$ Lihat Wahbah al-Zuhaili, op.cit., , jilid 1, h. 421

${ }^{19}$ Fungsi al-Qur'ân seperti ini dapat dilihat penjelasan Allah SWT dalam surat alBaqarah, ayat 185. Bulan Ramadhan, bulan yang di dalamnya diturunkan al-Qur'ân sebagai petunjuk bagi manusia dan penjelasan-penjelasan mengenai petunjuk itu dan pembeda (antara yang hak dan yang bathil).

${ }^{20} \mathrm{Ibn}$ Hazm, op.cit., h. 308

${ }^{21}$ Ibid., h. 310

$22 \mathrm{Abu}$ Abdillah Muhammad ibn Ahmad al-Anshari al-Qurthubi, selanjutnya ditulis Qurthubi, al-Jami' li Ahkam al-Qur'an, ( Beirut: Daar al-Kutub al-Ilmiah, 1993), j. 2, h. 4

${ }^{23}$ Abu al-Fida' al-Hafizh Ibn Katsir al-Dimasyqy, selanjutnya ditulis Ibn Katsir, Tafsir al-Qur'an al-'Azhim, (Beirut: Daar al-Fikr, 1992), j. 1, h. 146 
${ }^{24}$ Muhammad Quraish Shihab, Tafsir Al-Misbah: Pesan, kesan dan Keserasian al-Qur'an, ( Jakarta: Lentera Hati, 2000), Jilid 1, h. 226

${ }^{25}$ Muhammad Jamaluddin al-Qasimi, selanjutnya ditulis Qasimi, Tafsir al-Qasimi, (Beirut: Daar al-Kutub al-Ilmiah, 1997 ), jilid 3, h. 139

${ }^{26}$ Ibn Hazm, Al-Ihkâm ..., op.cit., h. 97

${ }^{27}$ Ibid., jilid 2, h. 5

${ }^{28}$ Ibn Hazm, Al-Fashl fi al-Milal wa al-Ahwa' wa al-Nihal, (Cairo: ttt.tt.), jilid 2, h. 126

${ }^{29} \mathrm{Ibid} .$, h. 95

${ }^{30}$ Muhammad Abed al-Jabiri, Takwin al-'Aql al-'Arabi, alih bahasa oleh Imam Khoiri, (Yogyakarta: IRCiSoD, 2003), cet. 1, h. 500

${ }^{31}$ Mengenai penjelasan Ibn Hazm tentang bayan dan bentuk-bentuknya ini dapat dilihat dalam Al-Ihkâm fi Ushûl al-Ahkâm,op.cit., jilid 1, h. 79-93.

32 Ibn Hazm, Al-Ihkam ...op.cit., jilid 1, h. 403

${ }^{33}$ Ibid. h. 414

${ }^{34}$ Abu Bakar Ahmad ibn Ali al-Razi al-Jassas, lebih lanjut ditulis al-Jassas, Ahkam alQur'an, (Beirut: Daar al-Kutub al-Ilmiah, t.th), jilid 2, h. 510

${ }^{35}$ Lihat Abu al-Fadl Jamal al-Din Muhammad ibn Mukrom Ibn Manzur al-Afriqî alMishrî, selanjutnya ditulis Ibn Manzur, Lisân al-'Arab, (Beirut: Dâr al-Shâdr, 1990), jilid 13, h. 225-226

${ }^{36}$ Penggunaan kata sunnah dengan makna perlakuan Tuhan (sering disebut hukum alam) terhadap umat terdahulu, dapat dilihat dalam al-Qur'ân surat al-Ahzab ayat 62. “ Sebagai sunnah Allah yang berlaku atas orang-orang yang telah terdahulu sebelummu, kamu sekali-kali tidak akan mendapati perubahan pada sunnatullah.

${ }^{37}$ Lihat Ahmad Hasan, The Early Development of Islamic Jurisprudence, alih bahasa oleh Agah garnadi, (Bandung: Pustaka, 1984), h. 76

38 Yasin Dutton, The Origins of Islamic Law: the Qur'an, the Muwaththa' and Madinah 'amal, alih bahasa oleh M. Maufur, ( Jokjakarta: Islamika, 2003), h. 342

${ }^{39}$ Ibid., h. 78

${ }^{40}$ Ibid., h. 79

${ }^{41}$ Teks ayat yang dijadikan Ibn Hazm sebagai dasar untuk memposisikan sunnah sebagai sumber hukum, telah dikemukakan sewaktu menjelaskan kedudukan al-Qur'an sebagai sumber hukum.

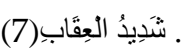

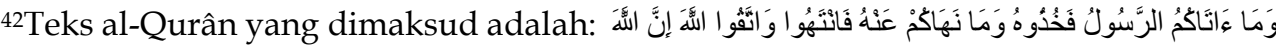

${ }^{43}$ Abu Ja'far Muhammad ibn Jarir al-Tabari, Tafsir al-Thabari: Jami' al-Bayan fi Takwil al-Qur'an, (Beirut: Daar al-Fikr, t.th), jilid 8, h. 299

${ }^{44}$ Qasimi, op.cit., jilid 7, h. 82

${ }^{45}$ Lihat Al-Jassas, op.cit., jilid 3, h. 616

${ }^{46} \mathrm{Ibn}$ Hazm, Al-Ihkam..., op.cit., h. 96

47 Pembagian hadis berdasarkan kuantitas perawinya pada mutawatir dan ahad, mereka memasukkan hadis masyhur ke dalam kelompok hadis ahad. Lihat Mahmud alThahhan, Taisir Musthalah al-Hadîts, (Daar al-Qur'ân al-Karîm, 1979), h. 18. Ulama lain mengkasifikasikan hadis berdasarkan jumlah perawinya pada tiga yaitu; mutawatir, masyhur dan ahad. Lihat Muhammad 'Ajaj al-Khatîb, Ushûl al-Hadîts: 'Ulûmuhu wa Mushthalahuhu, (Beirut: Dâr al-Fikr, 1989), h. 300 
${ }^{48}$ Ibn Hazm, Al-Ihkâm, ... op.cit., h. 102

${ }^{49}$ Ibid., h. 103

${ }^{50}$ Secara bahasa, adil dipahami sebagai "tidak berat sebelah, tidak sewenangwenang, tidak memihak juga berarti sepatutnya". Lebih lanjut lihat W.J.S. Purwadarminta, Kamus Umum Bahasa Indonesia, (Jakarta: Balai Pustaka, 1985), cet. Ke 8, h. 16. Dalam bahasa Arab kata 'adl merupakan kata jadian dari 'adala-ya'dilu, yang memiliki arti "keadilan, pertengahan, lurus dan memihak kepada kebaikan". Selanjutnya lihat Ibn Manzur, op.cit., jilid 13, h. 456. Adil menurut terminologi muhaddisin berbeda antara seorang ulama hadis dengan ulama hadis lainnya. Al-Hakim (w. $405 \mathrm{H}=1014 \mathrm{M}$ ) misalnya, membuat kriteria 'adil pada; Beragama Islam, tidak berbuat bid'ah dan tidak berbuat maksiat. Lebih lengkap tentang kriteria adil menurut ulama hadis dapat dilihat ikhtisar yang dibuat M. Syuhudi Ismail. Lihat M.Syuhudi Ismail, Kaedah Kesahihan Sanad Hadis: Telaah Kritis dan Tinjauan dengan Pendekatan Ilmu Sejarah, (Jakarta: Bulan Bintang, 1995), h. 130. Bila dilihat kriteria Ibn Hazm tentang adil, lebih ditekankan pada unsur pengamalan ajaran agamanya, yakni orang yang disebut adil adalah orang yang konsisten dalam menjalankan kewajiban dan konsisten pula dalam menghindari larangan syari'at. Lihat Ibn Hazm, Al-Ihkam...op.cit., h. 138

${ }^{51}$ Ibid., h. 106

52Lihat Syaukani, Irsyâd al-Fuhûl, (Dâr al-Fikr, tth), h. 71

${ }^{53}$ Lihat Muhammad Hudlari Bek, Ushûl al-Fiqh, (Kairo: Dâr al-Fikr, 1969), h. 271

${ }^{54}$ Ahmad Hasan, op.cit., h. 51

${ }^{55}$ Teks nash al-Qur'an yang dimaksud telah dimuat ketika menjelaskan fungsi alQur'an sebagai sumber utama hukum Islam pada poin A dalam bab ini.

${ }^{56}$ Lebih lanjut lihat Ibn Hazm, Al-Ihkam...op.cit., h. 542

${ }^{57}$ Qurthubi, op.cit., jilid 12, h. 194

${ }^{58}$ Thabari, op.cit., jilid 9, h. 341

${ }^{59}$ Lihat Ibn Hazm, Al-Ihkâm ... op.cit., h. 544

${ }^{60}$ Adapun alasan yang dikemukakan dalam mazhab Malik tersebut adalah: (1) Madinah merupakan kota hijrah rasul SAW., tempat turunnya wahyu, tetapnya agama Islam, tempat berkumpulnya para sahabat, karena itu tidak terjadi penyimpangan. (2) Penduduk kota Madinah menyaksikan turunnya wahyu, mendengarkan takwil dan mereka lebih mengetahui hal ihwal rasul. (3) Periwayatan di kalangan penduduk kota Madinah lebih dahulu jika dibandingkan dengan penduduk kota lainnya, karena itu kesepakatan (ijma') mereka menjadi hujjah bagi lainnya. Alasan mazhab malik ini dapat dikemukakan oleh AlAmidi, Al-Ihkâm fî̀ Ushâl al-Ahkam, (Beirut: Dâr al-Fikr, tth), jilid 1, h. 125

${ }^{61}$ Ibn Hazm, op.cit., jilid 1, h. 539

${ }^{62}$ Istishhab pada awalnya mengandung makna "pengakuan terhadap hubungan pernikahan". Lihat Abdul Wahab Khalaf, Ilm Ushîl al-Fiqh, alih bahasa oleh Masdar Helmy, (Bandung: Gema Risalah Press, 1997), h. 152. Dalam istilah mujtahid, istishhab diartikan sebagai "menetapkan hukum sesuatu menurut keadaan yang terjadi sebelumnya, sampai ada dalil yang merubahnya". Mukhtar Yahya dan Fatchurrahman, Dasar-dasar Pembinaan Hukum Fiqh Islami, (Bandung: PT.Al-Ma'arif, 1986), h. 111

${ }^{63}$ Lebih lanjut tentang istilah istishhab ini dapat dilihat Abu Hamid Muhammad ibn Muhammad al-Ghazâlî, selanjutnya ditulis Ghazali, Al-Mustashfa min 'Ilm al-Ushûl, (Beirut; Dâr al-Fikr, t.th), jilid 1, h. 218, bandingkan dengan Hudlori Bek, op.cit., h. 353-354 
${ }^{64}$ Lihat Abu Zahrah, Târîkh al-Mazâhib al-Islâmiyah fî̀ Târîkh al-Mazâhib alFiqhiyah, (Kairo: Dâr al-Fikr al-Arabî, t.th), h. 411

${ }^{65}$ Wael B. Hallaq, A History of Islamic Legal Theories, alih bahasa oleh E. Kusnadiningrat dan Abdul Haris bin Wahid, (Jakarta: Rajawali Pers, 2001), h. 167

${ }^{66} \mathrm{Ibn}$ Hazm, Al-Ihkam..., op.cit., jilid 2, h. 3

${ }^{67}$ Ibid., h. 6

${ }^{68} \mathrm{Ibid}$.

${ }^{69}$ Ibid.

${ }^{70}$ Dalam ilmu keislaman terdapat dua istilah lagi yang seakar dengan kata ijitihad, yaitu jihad dan mujahadah. Istilah ijtihad biasa digunakan dalam istilah ushul al-figh dan tidak jarang pula digunakan dalam istilah pemikiran Islam lainnya yang pengertiannya mengacu kepada pengerahan kemampuan intelektual secara optimal untuk menemukan solusi hukum atau untuk mendapatkan pengetahuan. Pengertian seperti ini tercermin dari hadis yang diriwayatkan Ahmad ibn Hanbal dari Mu'adz, yakni ketika rasulullah saw. mengutusnya menjadi hakim di Yaman, rasulullah saw bertanya kepada Mu'adz sebagaimana dalam terjemahan hadis berikut;

"Bagaimanakah engkau mengambil tindakan hukum yang dihadapkan kepadamu, hai Mu'adz ? Ia menjawab, aku akan menetapkan hukum atas dasar kitab Allah SWT. Nabi bertanya lagi, bagaimana jika tidak engkau temui dalam kitab Allah SWT ?. Ia menjawab, aku akan menetapkan berdasarkan sunnah rasulullah saw. Nabi saw. bertanya lagi, bagaimana jika tidak engkau temukan dalam sunnah rasulullah saw.? Ia menjawab, aku akan putuskan berdasarkan ra'y-ku dan aku akan berusaha keras. Rasulullah saw menepuk-nepuk dada Mu'adz seraya bersabda; segala puji bagi Allah SWT yang telah memberikan taufiq kepada utusan rasulullah sesuai dengan yang diridhai Allah dan rasul-Nya. Hadis ini dapat dilihat Abu Daud, Sunan Abu Daud, (Kairo: Musthafa al-Bab alHalabi, 1952), jilid 2, h. 272 lihat juga Tirmidzi, Sunan Tirmidzi, (Beirut: Daar al-Fikr, 1967), jilid 1, h. 157. Pada hadis ini dijumpai kalimat "ajtahidu bi ra'yi" (aku akan berijtihad dengan pikiranku), dari ungkapan ini terlihat bahwa ijtihad mengacu kepada aktivitas penalaran intelek.

Kata jihad biasa dipakai sebagai terminologi fiqh, yang pengertiannya lebih ditekankan pengerahan kemampuan fisik secara maksimal dalam menegakkan agama Allah SWT. Pengertian ini terlihat pada maksud ayat 52 surat al-Furqan; "maka janganlah kamu mengikuti orang-orang kafir dan berjihadlah terhadap mereka dengannya (al-Qur'an) sebagai jihad yang besar".

Jika pada fiqh terminologi jihad lebih mengarah kepada pengerahan aktivitas fisik, tasawuf juga memakai istilah tersebut, tetapi lebih banyak mengacu kepada aktivitas keruhanian. Meski demikian, istilah yang paling dominan digunakan dalam tasawuf adalah mujahadah, yakni pengerahan kemampuan jiwa (nafs) untuk dapat menaklukkan hawa nafsu dan syetan. Pengertian ini dipahami dari Firman Allah SWT. "Dan orang-orang yang bermujahadah menuju Kami, benar-benar akan kami tunjukkan kepada mereka jalan-jalan kami".(Q.S. al-Ankabut; 69)

Meskipun ketiga istilah tersebut memiliki karakteristik sendiri-sendiri, dari segi kebahasaan, ketiganya tetap memiliki akar kata yang sama dan mengandung makna dasar "pengerahan daya, kemampuan, kesanggupan dan kekuatan dalam menghadapi sesuatu yang sulit." Bertolak dari pengertian kebahasaan di atas, terlihat adanya benag merah yang menghubungkan ketiga istilah tersebut sehingga sulit memisahkan antara satu dengan lainnya secara tajam, karena satu aktivitas memiliki kaitan dengan kegiatan lainnya. Lihat 
Ibn Qayyim al-Jauziyah, I'lâm al-Muwaqqi'in, (ed). Muhammad Muhy al-Din 'Abd alHamid, (beirut: Daar al-Fikr, 1977), jilid 1, h. 88-89

${ }^{71}$ Lihat Ibn Manzur, Lisân al-Arab, (Beirut: Daar al-Shadr, t.th.), jilid 9, h. 133

${ }^{72}$ Lihat Muhammad ibn Ali ibn Muhammad al-Syaukani, selanjutnya ditulis Syaukani Irsyad al-Fuhul ilâ Tahqiq al-Haq min 'Ilm al-Ushul, (Beirut: Dâr al-Fikr, t.th), h. 250

${ }^{73}$ Lihat Ibn Hazm, Ihkam...op.cit., jilid 2, h. 269

${ }^{74}$ Lihat Abu Hamid Muhammad ibn Muhammad al-Ghazali, lebih lanjut ditulis Ghazali, Al-Mustashfa min 'Ilm al-Ushûl, (Beirut: Dar al-Fikr, t.th.), jilid 2, h. 362

${ }^{75}$ Ibid., lebih jelas definisi tersebut adalah:

$$
\text { بذل المجتهد وسعه فى طلب العلم بأحكام الثريعة . }
$$

${ }^{76}$ Lebih lanjut lihat Saif al-Din Abu al-Hasan Ali ibn Abu Ali ibn Muhammad alAmidi, selanjutnya ditulis Amidi, Al-Ihkam fi Ushûl al-Ahkâm, (Beirut: Daar al-Fikr, 1996), jilid 4, h. 309 Adapun teks definisi tersebut adalah:

"Ibn Hazm, loc.cit.

$$
\text { فى طلب الظن بشيء من الأحكام الثر عية على وجه يحس من النفس العزز عن المزيد فيه. }
$$

${ }^{78} \mathrm{Ibid}$.

${ }^{79} \mathrm{Abu}$ Bakar Muhammad Ibn Abdullah Ibn Arabi, selanjutnya ditulis Ibn Arabi, Ahkam al-Qur'an, ( Beirut: Daar al-Fikr, 1988), jilid 2, h. 40

${ }^{80}$ Wahbah al-Zuhaili, Al-Tafsir al-Munir fi al-'Aqidah wa al-Syari'ah wa al-Manhaj,

(Beirut: Daar al-Fikr, 1998), jilid 6, h. 84

${ }^{81}$ Ibid., jilid 7, h. 197

${ }^{82}$ Fakhruddin al-Razi, Al-afsir al-Kabir (Mafatih al-Ghaib), ( Beirut: Daar al-Fikr, 1990), jilid 12, h 177

${ }^{83}$ Muhammad Jamal al-Din al-Qasimi, Tafsir al-Qasimi (Mahasin al-Takwil), ( Beirut: Daar al-Kutub al-Ilmiah, 1997), jilid 6, h. 401-402. Bandingkan dengan Abu Ja'far Muhammad ibn Jarir al-Thabari, Tafsir al-Thabari (Jami' al-Bayan fi Takwil al-Qur'an), ( Beirut: Daar alKutub al-Ilmiah, 1999), jilid 7, h. 633-634

${ }^{84}$ Konsep al-dalil merupakan metode ijtihad hukum Islam yang hanya dimiliki oleh Ibn Hazm, hal ini merupakan penalaran terhadap al-Qur'an, sunnah dan ijma', namun bukan dalam bentuk qiyas, tetapi bentuk lain yang didasarkan kepada istilah-istilah logika.

${ }^{85}$ Lihat Ibn Hazm, Al-Muhalla, (Beirut: Dâr al-Jail, t.th.), jilid 1, h. 76-77 Lebih lanjut lihat penjelasan Faruq 'Abd al-Mu'thî, A'lâm al-Fuqahâ' wa al-Muhaddisîn: Ibn Hazm alZhâhirî, (Beirut: Dâr al-Kutub al-Ilmiah, 1992), h. 90-91

${ }^{86}$ Lihat Ibn Hazm, Ihkâm...op.cit., jilid 1, h. 97-98

${ }^{87}$ Untuk menelusuri pendapat Ibn Hazm tentang wajibnya ijtihad bagi setiap pribadi umat Islam dapat dilihat Ibn Hazm, Al-Muhallâ, op.cit., jilid 1, h. 66-67

${ }^{88}$ Suryan A. Jamrah, Pemikiran Kalam Ibn Hazm al-Andalusi, (Pekanbaru: Susqa Press, 1998), h. 26

${ }^{89}$ Berbeda dengan ulama ushul lainnya, mereka mendasarkan epistemologi hukum Islamnya pada al-Qur'an, sunnah, ijma', qiyas serta metodologi istimbath lain yang punya krakteristik tersendiri, Malik dengan maslahah al-mursalah-nya, Abu Hanifah dengan istihsannya.

${ }^{90}$ Lihat Ibn Hazm, Ihkam...op.cit., jilid 2, h. 100-101

${ }^{91}$ Lihat Wahbah al-Zuhaili, Ushûl al-Fiqh al-Islâmî, (Beirut: Daar al-Fikr, 1986), jilid 1, h. 603. Lihat juga Abu Abdullah Muhammad ibn Umar ibn al-Husein Fakhruddin al-Razi, 
Al-Fikra: Jurnal Ilmiah Keislaman, Vol. 3, No. 2, Juli-Desember 2004

Al-Mahshul fi 'Ilm al-Ushul, (Beirut: Daar al-Kutub al-Ilmiah, 1999), jilid 2, h. 215 bandingkan dengan Saifuddin abu al-Hasan Ali ibn Abi Ali ibn Muhammad al-Amidi, selanjutnya ditulis Amidi, Al-Ihkam fi Ushul al-Ahkam, Beirut: Daar al-Fikr, 1996), jilid 4, h. 130 